\title{
An Empirical Investigation of Leader Identity Formation and Implications for Executive Coaching and Leadership Development
}

\author{
Suzette Skinner \\ Sydney, \\ Australia
}

\begin{abstract}
This article addresses a gap in understanding about leader identity, specifically its formation across the course of an individual's life, and the impact of identity enablers and derailers on this process. To begin to address this gap, this article reports survey data exploring these aspects of identity formation with a global, working adult population $(\mathrm{n}=1018)$. Results provide empirical support for identity formation as a dynamic, variable process. Results also indicate a positive correlational relationship between the strength of an individual's leader identity and the specific leader identity enablers reported in the leader identity literature. Together these findings provide preliminary, empirical support for Leader Identity Formation Theory (LIFT), whilst also suggesting areas for future research. Given the role of leader identity in enabling enhanced leader effectiveness, the practical implications of these results for executive coaching and leadership development are also discussed.
\end{abstract}

Keywords: leader identity formation theory, leader identity coaching, executive coaching, leadership development, enablers, derailers

\section{Introduction}

If one doesn't see themselves as a 'leader', can we expect them to lead effectively, if at all?

Effective and sustainable leadership development, including executive coaching, is enabled through leader identity work. Leader identity is defined as a sub-component of one's sense of self that includes their "leadership schemas, leadership experience and future representations of oneself as a leader" (Epitropaki et al., 2017, p. 9). As an approach to development, leader identity work in executive coaching involves exploring an individuals' schemas about leading, as well as their personal experience of identity constraints and

This is an Open Access article distributed under the terms of the Creative Commons Attribution (CC BY) License which permits use, distribution and reproduction in any medium, provided the original work is properly cited. 
enablers, such that they might bring to life their unique identity as a leader (Hammond, Clapp-Smith \& Palanski, 2017; Skinner, 2014, 2020).

A leader identity approach to executive coaching and leader development emphasises the importance of the intrapersonal dynamics within every individual, which are less visible, and yet foundational, to their leader performance (Chui Lai Man, 2018; Hammond et al., 2017; Day \& Dragoni, 2015). Empirical support for leader identity as a platform for individuals to take step into leadership, and for leader effectiveness, continues to grow (Epitropaki, Kark, Mainemelis, \& Lord, 2017; Kragt \& Day, 2020; Kragt \& Guenter, 2018). The leader identity literature highlights the foundational role of an individual's leader identity in accelerating the adoption of leadership skills; increasing their initiative taking, enhancing their motivation to lead, and building their selfconfidence is doing so (Chui Lai Man, 2018). Furthermore, a strong leader identity has also been shown to intrinsically motivate individuals to become more purposeful in leading (Acton, Foti, Lord, \& Gladfelter, 2019; Clark, 2018).

Within our understanding of the multi-dimensional nature of the self (Bachkirova, 2016b), leader identity represents an aspect of the self that is dynamically activated based on context. This sub-component of an individual's identity is specific to "being a leader or how one thinks of oneself as a leader" (Day \& Harrison, 2007, p. 365). It is comprised of memories, beliefs and emotions about past experiences, future possible selves and leadership schemas formed over an individual's life (Epitropaki et al., 2017; Murphy \& Johnson, 2011). One's leader identity represents a deeper level knowledge structure from which leadership behaviours, and competencies arise (Kragt \& Day, 2020). In essence, one's leader identity shapes one's leader behaviours (Johnson, Venus, Lanaj, Mao, \& Chang, 2012; Lord, Epitropaki, Foti, \& Hansbrough, 2020). The multiplicity of identities within each individual (Bachkirova, 2016a) means that individuals are considered to hold a range of identities within their self-concept, of which leader identity is one aspect. Adopting a leader identity perspective involves actively assisting individuals to internalise and embody a leader identity, enhancing their identity coherence and integrating this aspect of their identity within their broader self-concept (Markus \& Wurf, 1987; Skinner, 2020).

Executive coaching can provide powerful sense-making opportunities for individuals to critically explore, craft and develop their personalised leader narrative, supporting their growth as a leader (Hammond, Clapp-Smith, \& Palanski, 2017; Skinner, 2014). Organisationally, identity perspectives in 
leadership development may actively address potential tensions between individual expectations for leading (including their internal knowledge structures) and potential differences in collective leadership expectations (such as accepted cultural norms for leading). By fostering the individual's own interpretation of leading, individuals may be enabled to connect more meaningfully and authentically to their organisation's espoused leadership attributes and norms. In adopting a leader identity perspective within executive coaching and leadership development initiatives, organisations and individuals co-create customised leadership development pathways. These pathways incorporate both the individualised leader identity development needs, specific to each leaders' unique history and life context, and the broader organisational leadership environment, illuminating areas for development and adaptation.

\section{Leader Identity Formation Theory (LIFT)}

Leader Identity Formation Theory (LIFT) (Skinner, 2014; 2015; 2020) proposes a dynamic formation process of internalising a leader identity, which is impacted by the enabling and derailing factors that individuals may encounter. By proposing that leader identity develops across both the course of an individual's life and multiple life domains (e.g., work, family, community), LIFT predicts that considerable between-person variability is likely to exist. As shown in Figure 1, this identity formation process involves at least three stages of internalisation: under-developed, forming and well-developed. These stages are akin to identity transitions (Ibarra, 1999), as individuals move through stages of not identifying as a leader (Under-developed), through to establishing and acknowledging their identity (Forming) and then recognising the uniqueness of their leader identity, within their broader set of identities (Welldeveloped). The Under-developed leader identity stage represents a positive frame on leader identity, normalising this formation stage for individuals and helping them access possible leadership qualities across different domains in their life, to support their leadership growth.

LIFT incorporates the influence on identity of various domains, such as family, community and work. This broader, life-based, recognition of leader identity formation assists individuals in integrating their leadership experiences and attributes across all their life domains, enhancing the coherence of their leader identity with other aspects of their identity. LIFT defines leader identity formation as:

A process that forms and reforms over an individual's lifetime, through encountering a series of subjectively experienced intrapersonal, 
relational, and collective-level enablers and derailers. Leader identity experimentation and formation occurs cognitively, emotionally, and socially across all life domains. (Skinner, 2020)

As outlined in Figure 1, LIFT makes explicit the ongoing, active identity formation process, as individuals engage in sensemaking involving their experiences and the various identity enablers and derailers they experience. LIFT suggests coaching practitioners consider identity transitions with their clients, investigating the formation stage of their client's leader identity and looking beyond external factors (such as organisational position or title) as indicators of a client's leader identity strength.

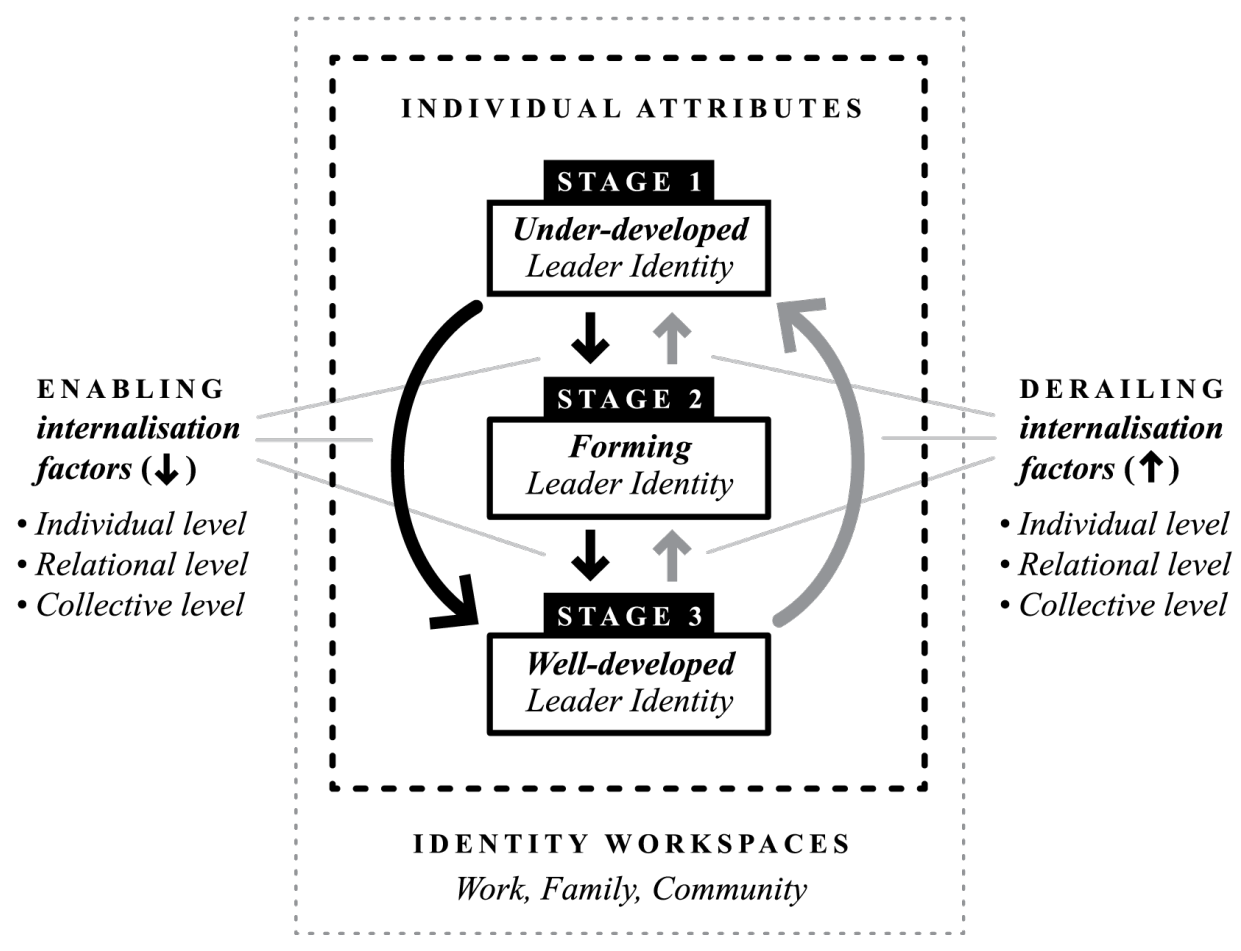

Figure 1: Leader Identity Formation Theory (LIFT; Skinner 2020)

The dynamic, recursive process proposed within LIFT makes explicit the concept of identity gains and losses referred to in the leader identity literature (DeRue \& Ashford, 2010). Notably, each of the downward arrows in the LIFT process (Figure 1) represent a deeper internalisation of one's leader identity within their self-concept. Conversely the upward arrows in Figure 1 represent the ways in which one's leader identity can be undermined or 
destabilised. As such, the LIFT model highlights the cyclical nature of identity formation as individuals cycle between stages, based on their life experiences (Skinner, 2020).

\section{Formation across the Lifespan}

Several researchers have highlighted that the formation of a leader identity begins in childhood, influenced by the individual's family of origin and their engagement in various sporting activities, community projects and educational endeavours (Clapp-Smith et al., 2019; Hammond et al., 2017; Liu et al., 2019; Murphy \& Johnson, 2011). This perspective incorporates a lifebased approach to leader formation where individuals start to establish their ideas (schemas) of what leadership means to them, from their earliest experiences. These experiences also influence how strongly individuals see themselves as a leader, based on their unique background and their selfdefinitions for leading (Murphy \& Johnson, 2011).

LIFT builds on research by Markus and Kunda (1986) that highlighted that identity strength, and the degree to which this identity is activated, varies across context and time. Currently, studies specific to the leader identity domain are limited to measuring changes in leader identity following leadership development programs. These studies reveal that the strength of one's leader identity changes over shorter interventions ranging from several weeks to five months (Kragt \& Day, 2020). These studies also confirm that variation in leader identity strength can occur in a mutually reinforcing manner with skill acquisition - as leader identity strength increases, leadership skill acquisition increases; as leadership skill acquisition increases, leader identity strength increases (Day \& Sin, 2009; Miscenko, Guenter, \& Day, 2017).

LIFT conceptualises identity formation across an individual's life, moving through different stages of formation over time (Figure 1), which informs Hypothesis 1:

H1: The strength of an individual's leader identity will vary across the course of their life.

Investigating the strength and variability of an individual's leader identity, over broader life periods, is not evident in the leader identity literature to date.

\section{Impact of Enablers and Derailers on Leader Identity Formation}


As individuals engage in their life experiences, they encounter a variety of factors that can strengthen (enable) or undermine (derail) their leader identity formation process (DeRue \& Ashford, 2010; Skinner, 2014). According to LIFT, the forming of one's leader identity occurs across multiple levels: individual, relational and organisational, as individuals internalise various multidomain life experiences (see Figure 1). These identity enablers and derailers can support or counter the internalisation process, destablising or weakening an individual's sense of themselves as a leader (Ashforth \& Schinoff, 2016; Nyberg \& Sveningsson, 2014). Based on the individual's unique attributes, their experience with others and the context in which they lead, these enablers and derailers variably impact their formation process as a leader (Skinner, 2014, 2020).

A review of the leader identity literature revealed five themes related to leader identity Enablers, and two themes related to leader identity Derailers. As Epitropaki et al. (2017) points out, the published research focused on enabling and derailing factors is largely qualitative (Ibarra, 1999; Ladge, Clair, \& Greenberg, 2012; Lanka, Topakas, \& Patterson, 2019; Skinner, 2014; Zheng \& Muir, 2015), with no studies yet reported on the relationship between the various leader identity factors.

\section{Enabling factors supporting Leader Identity Formation}

The Enabling themes identified by the author are listed below, along with a brief description. At the Individual level these include: Change Readiness, Authenticity and Strengths. At the Relational and Collective level these include: Inclusivity, Social Resources and Validating Others.

\section{Change Readiness}

- Receptivity and preparedness of the individual to engage in leader identity work through leader development (Day \& Sin, 2009; Kragt \& Day, 2020).

2. Authenticity \& Strengths

- Establishing an authentic purpose as a leader (Skinner, 2014; Zheng \& Muir, 2015). From the perspective of multiplicity theory, this factor refers to the individual's specific purpose relative to their leader identity, a sub-component of their identity.

- Importance of personalising leadership and using one's unique strengths and voice as a leader (Romaniuk, 2014; Skinner, 2014; Zheng \& Muir, 2015).

3. Inclusivity 
- Importance of redefining masculine norms of leadership to include the individual's personalised identity as a leader (Hammond et al., Ladge et al., 2012; Romaniuk, 2014; Skinner, 2014).

- Positive impact of a positive leader identity as a female leader on one's motivation to lead (Clark, 2018; Karelaia \& Guillén, 2014).

4. Social Resources

- Focusing on others and recognising interdependencies of support (Zheng \& Muir, 2015).

- Importance of role models and mentors (Ibarra, Wittman, Petriglieri, \& Day, 2014; Lanka et al., 2019).

- Access to formal and informal networks for feedback and development (DeRue \& Myers, 2014; Skinner, 2014)

- Relational impact of claiming leadership for oneself and granting leadership for others, as a mutual process of identity growth (Marchiondo et al., 2015).

5. Validating Others

- Relational granting of leadership, validating the leadership claims and opportunities for others (Chui Lai Man, 2018; DeRue \& Ashford, 2010).

\section{Derailing factors undermining Leader Identity Formation}

The Derailing themes identified by the author, that undermine identity formation, are classified below:

1. Environment Derailers: These refer to obstacles encountered by an individual at the collective and relational level including:

- Organisational structures and rigid hierarchy that limit leadership initiative taking (Ladge et al., 2012; Lanka et al., 2019; Skinner, 2014).

- Gendered organisational norms for leadership reported in the literature, including identity threat (Petriglieri \& Stein, 2012). This also encompassed work/life balance challenges, which impact some individuals more than others (Guillén, Mayo, \& Korotov, 2015; Skinner, 2014).

- Organisational cultures which do not validate an individual's claims to leadership, or which do not grant leadership to others outside of formal titles (Marchiondo et al., 2015; Nyberg \& Sveningsson, 2014).

2. Self Derailers: These refer to individual level derailers that an individual may encounter including:

- Self-barriers to identity development including self-limiting schemas for leadership and negative self-talk (Petriglieri, 2011). 
- Low self-awareness of potential identity derailers (Skinner, 2014).

- Low self-belief in one's capacity to lead (low leader self-efficacy) (Clark, 2018; Skinner, 2020; Zheng \& Muir, 2015).

Hypothesis two is informed by the range of identity enablers and derailers identified:

H2: Leader identity will be positively related to Enablers, and also Derailers (as high scores are indicative of low derailer impact).

The potential impact of individually experienced enablers and derailers on an individual's unique leader identity (Figure 2), represents potential areas for exploration in executive coaching and leadership development interventions. The following sections detail the process and procedures investigating these relationships. This section is followed by suggested applications of LIFT in executive coaching and leadership development interventions.

\section{Methods}

A two-part survey was developed by the author, intended to investigate the lifespan variability of an individual's perceived leader identity (H1). The relationship of an individual's leader identity with the reported enablers and derailers (H2) was also developed in Part 2 of the survey. Survey items were constructed based on the lifespan identity formation literature (Part 1) and identity enablers and derailers literature (Part 2), as proposed within the LIFT model.

\section{Participants}

Purposive sampling was conducted with participants sourced from a range of multinational organisations in Australia, United States, Singapore, India, and UK. Participants were asked to complete the survey prior to their engagement in an integrated executive coaching and leadership development program. Permission for the use of participant data was provided by each participant as part of their survey completion. All collected data was treated anonymously.

The survey was initiated with an adult working population $(\mathrm{n}=1,018)$, with $50 \%$ of participants employed in managerial roles and $50 \%$ in individual contributor roles. The largest age range of participants was 26-35 years. 
Participants were employed across a range of industries and geographic locations. Demographic information is presented in Table 1.

Table 1: Participant Demographics

\begin{tabular}{l|l|l|l}
\hline Gender & Age & Geographic Location & Main Industries \\
\hline $54 \%$ Female & $18-25: 7 \%$ & Australia: $68 \%$ & High tech: $20 \%$ \\
\hline $45 \%$ Male & $26-35: 58 \%$ & United States: $17 \%$ & Manufacturing: $15 \%$ \\
\hline $1 \%$ No response & $36-45: 26 \%$ & Singapore: $9 \%$ & Consumer Goods: $12 \%$ \\
\hline & $46-55: 6 \%$ & India: $4 \%$ & Services/Banking: $11 \%$ \\
\hline & $56-65: 2 \%$ & UK: $2 \%$ & Food/Hospitality: $11 \%$ \\
\hline
\end{tabular}

\section{Measures}

Data was collected using the two-part self-report survey instrument described below.

Lifespan survey (Part 1). Survey questions were developed to investigate leader identity strength across five different periods in their life (Hammond et al., 2017; Lord \& Hall, 2005). Based on the identity formation process beginning in childhood (Liu et al., 2019; Murphy \& Johnson, 2011), participants were asked how strongly they identified as a leader today, and retrospectively one year ago; during young adulthood (up to 29 years); during teenage years; and during childhood.

Table 2: Survey responses aligned to the proposed LIFT formation stage

"My sense of myself as a leader..."

\begin{tabular}{l|l}
\hline Self-Rating & Proposed LIFT Stage \\
\hline $1=$ Definitely a part of me & Well-developed Identity Stage \\
\hline $2=$ Very much a part of me & Well-developed Identity Stage \\
\hline $3=$ Somewhat a part of me & Forming Identity Stage \\
\hline $4=$ Not a part of me & Under-developed Identity Stage \\
\hline
\end{tabular}




\begin{tabular}{l|l}
\hline $5=$ Not at all a part of me & Under-developed Identity Stage \\
\hline
\end{tabular}

Note: Individual ratings were provided for today, one year ago, young adulthood, teenage years, and childhood

These lifespan questions were designed to assess the extent to which participants' leader identities changed through these periods (either formed or reformed). Survey questions focused on the self-referent aspect of identity formation, a subjective factor best accessed via self-report (Hammond et al., 2017). These questions were mapped to the developmental phases proposed in the LIFT model (see Figure 1), with items scored using a 5-point Likert scale (as shown in Table 2).

Identity Enabler and Derailer survey (Part 2). Items were created for each of the factors identified in the leader identity literature, (Part 2 of the online survey). A total of 45 survey items were developed. Sample items and the number of items for each factor are shown in Table 3.

Table 3: Sample items from Leader Identity Enablers and Derailers survey

\begin{tabular}{l|c|l}
\hline Identified Factor & Items & Sample survey items \\
\hline Change Readiness & 5 & I regularly review and adapt my development. \\
\hline Strengths and Authenticity & 6 & I work to my strengths and values. \\
\hline Inclusivity & 6 & I can readily identify gender bias or stereotypes. \\
\hline Social Resources & 7 & I have a range of mentors to support me at work. \\
\hline Validating Others & 5 & Praising others for their leadership actions is a regular part of my week \\
\hline Environmental Derailers & 4 & Being promoted to senior ranks is available to everyone based on merit. \\
\hline Self Derailers & 4 & I am aware of the kinds of things that derail me. \\
\hline
\end{tabular}

Note: Items were scored using a 5-point Likert scale, where:

$1=$ Not at all, $2=$ Maybe, $3=$ Sometimes, $4=$ Yes, $5=$ Yes Definitely, or N/A = Not Applicable

Given the literature supporting leader identity as an enabler for leadership effectiveness, items for the Leader Identity factor were developed based on the literature as well as adapted from the Professional Identity Questionnaire (Weiss \& Fisherman, 2011). Derailer items were focused on obstacles associated with identity formation. This included environmental factors such as perceived lack of organisational support and gendered leadership norms (Ashforth \& Schinoff, 2016; Skinner, 2014), and individually focused factors 
(i.e. self) such as awareness of self-limiting beliefs. It should be noted that derailer items were worded in such a way that high scores would indicate a low level of impact on leader identity (and vice versa).

\section{Data Analysis and Discussion}

Analysis of the lifespan survey data (Part 1) revealed the following:

- $94 \%$ of the sample population experienced variance in their leader identity strength over the five life periods.

- $76 \%$ of the sample reported two or more variations in leader identity strength across the LIFT formation stages (e.g., moving from WellDeveloped to Forming, or from Forming to Well-Developed). Such increases and decreases in identity strength suggest that individuals may internalise a Well-Developed identity during one period of their life, only to have it undermined during another (with a movement back to a Forming or Under-developed stage).

- $6 \%$ of the sample identified consistently as a leader across all of their life periods (at either the Forming or Well-developed stage), whereby their formation stage remained the same. This highlighted a small percentage of the sample population that did not vary in the strength of their leader identity.

These results offer some support to a core premise of LIFT. That is, they suggest that one's leader identity dynamically forms and reforms, strengthens and weakens, across different life periods, becoming more or less internalised based on the factors they experience. This aligns with the findings of Day \& Sin (2009), which showed identity strength varied across a multi-week leader development program and a five-month leadership program (Kragt \& Day, 2020). The results also reflect findings that leader development programs may result in identity reformation (weakening or strengthening one's identity), as individuals internalise new perspectives and meaning of their identity as a leader (Miscenko et al., 2017).

In somewhat surprising results, $97 \%$ of participants' Today ratings reflected a Forming or Well-Developed identity stage. This indicates the vast majority of people saw leadership as being part of their identity (irrespective of age, gender and geography). Whilst this result may have been influenced by participants' enrolment in a leadership development program, it was also the 
case that $50 \%$ of participants were not in formal management roles and the survey was completed prior to their commencement of the program. As such, the data suggest that leader identity is not reliant on formal positions (Day, Fleenor, Atwater, Sturm, \& McKee, 2014; Lord et al., 2020), in keeping with notions of distributed leadership (Acton et al., 2019).

These results represent some preliminary support for Hypothesis 1. They indicate the centrality of leader identity in organisational life, and reinforce the importance of incorporating leader identity perspectives in leadership development for participants with and without formal titles (Day \& Dragoni, 2015). The results also suggest that individual leader identities may be more pervasive and central to development than previously recognised, particularly given that leader identity has been shown to be a motivator for leader initiative taking and performance (Kragt \& Guenter, 2018).

Before analyzing the identity Enabler and Derailer data set (Part 2), a reliability analysis was performed by computing the Cronbach's alpha estimate of internal consistency $(\alpha)$ for each scale. This approach was adopted to ascertain the estimated reliability for each identified factor, ensuring each item is reflective of each factor. This analysis revealed scale alphas ranging between .71 and .84 , with only the items for Self-Derailers (.63) falling outside the generally acceptable levels (Taber, 2018).

Having assessed scale reliability, a correlational analysis was performed and revealed significant, positive correlations $(\mathrm{p}<.001)$ between individual leader identity and all the enabling factors identified in the literature (see Table 3 ). The results of this correlational data revealed small to moderately strong positive correlation between leader identity and each of the identified factors (shown in Table 4). These positive correlations provide preliminary support for Hypothesis 2 and a key prediction of the LIFT model, that an individual's leader identity is supported by stronger identity enablers and weaker identity derailers.

These preliminary findings support and extend the small number of leader identity studies that measure changes in leader identity over time (Day \& Sin, 2009; Kragt \& Day, 2020; Miscenko, 2017; Miscenko et al., 2017). The results also provide initial empirical support for the dynamic lifespan approach of identity formation proposed in LIFT, most especially the bi-directional movement across the three life stage life stages (shown earlier in Figure 1). The observed correlations between identity strength and identity enablers offers preliminary support for the proposition for the role of these factors in forming 
one's leader identity. These findings align with findings by Chui (2018) involving leader identity claiming (choosing to lead) and granting behaviours (validating the leadership in others), confirming the critical role of intrapersonally and interpersonally factors in identity formation. As such, an understanding of the leader identity internalisation process seems practically worthwhile, given the role of identity in motivating individuals to lead and enhancing their leader effectiveness. The relevance of this work for executive coaching and other leadership development interventions seems undeniable and is the focus of the concluding section.

Table 4: Correlation matrix for Leader Identity Enablers and Derailers

\begin{tabular}{|c|c|c|c|c|c|c|c|c|c|}
\hline & & LID_Avg & Change_Avg & Strengths_Avg & Inclusivity_Avg & SR_Avg & VO_Avg & DEnv_Avg & DSelf_Avg \\
\hline \multirow[t]{3}{*}{ Leader Identity_Avg } & Pearson Correlation & 1 & $.545^{\circ}$ & $.455^{4}$ & .334 & $.372^{4}$ & .492 & $.260^{\circ}$ & .384 \\
\hline & Sig. (2-tailed) & & .000 & .000 & .000 & .000 & .000 & .000 & .000 \\
\hline & $\mathrm{N}$ & 1018 & 1018 & 1018 & 1018 & 1018 & 1018 & 1018 & 1018 \\
\hline \multirow[t]{3}{*}{ Change_Avg } & Pearson Correlation & $.545^{\circ}$ & 1 & $.386^{4}$ & $.329^{4}$ & $.395^{4}$ & $.478^{\prime \prime}$ & $.343^{\prime \prime}$ & $.412^{*}$ \\
\hline & Sig. (2-tailed) & .000 & & .000 & .000 & .000 & .000 & .000 & .000 \\
\hline & $\mathrm{N}$ & 1018 & 1018 & 1018 & 1018 & 1018 & 1018 & 1018 & 1018 \\
\hline \multirow[t]{3}{*}{ Strengths_Avg } & Pearson Correlation & $.455^{\circ}$ & $.386^{4}$ & 1 & $.388^{-1}$ & $.323^{4}$ & $.378^{\prime \prime}$ & $.380^{\circ}$ & .412 \\
\hline & Sig. (2-tailed) & .000 & .000 & & .000 & .000 & .000 & .000 & .000 \\
\hline & N & 1018 & 1018 & 1018 & 1018 & 1018 & 1018 & 1018 & 1018 \\
\hline \multirow[t]{3}{*}{ Inclusivity_Avg } & Pearson Correlation & .334 & $.329^{4}$ & $.388^{\prime \prime}$ & 1 & $.237^{4}$ & $.397^{\prime \prime}$ & $219^{*}$ & $.345^{\circ}$ \\
\hline & Sig. (2-tailed) & .000 & .000 & .000 & & .000 & .000 & .000 & .000 \\
\hline & $\mathrm{N}$ & 1018 & 1018 & 1018 & 1018 & 1018 & 1018 & 1018 & 1018 \\
\hline \multirow[t]{3}{*}{ Social Resources_Avg } & Pearson Correlation & .372 & $.395^{4}$ & $.323^{4}$ & $.237^{\circ}$ & 1 & .404 & $.413^{\prime \prime}$ & $.456^{\prime \prime}$ \\
\hline & Sig. (2-tailed) & .000 & .000 & .000 & .000 & & .000 & .000 & .000 \\
\hline & $\mathrm{N}$ & 1018 & 1018 & 1018 & 1018 & 1018 & 1018 & 1018 & 1018 \\
\hline \multirow[t]{3}{*}{ Validating Others_Avg } & Pearson Correlation & $.492^{\prime \prime}$ & $.478^{\prime \prime}$ & $.378^{-1}$ & $.397^{4}$ & $.404^{4}$ & 1 & $.316^{*}$ & $.357^{*}$ \\
\hline & Sig. (2-tailed) & .000 & .000 & .000 & .000 & .000 & & .000 & .000 \\
\hline & $\mathrm{N}$ & 1018 & 1018 & 1018 & 1018 & 1018 & 1018 & 1018 & 1018 \\
\hline \multirow[t]{3}{*}{ Derailers Environ_Avg } & Pearson Correlation & $.260^{\circ}$ & $.343^{4}$ & $.380^{\circ}$ & $.219^{-1}$ & $.413^{4}$ & $.316^{*}$ & 1 & $.371^{\prime \prime}$ \\
\hline & Sig. (2-tailed) & .000 & .000 & .000 & .000 & .000 & .000 & & .000 \\
\hline & $\mathrm{N}$ & 1018 & 1018 & 1018 & 1018 & 1018 & 1018 & 1018 & 1018 \\
\hline \multirow[t]{3}{*}{ Derailers Self_Avg } & Pearson Correlation & .384 & $.412^{4}$ & .412 & $.345^{4}$ & $.456^{4}$ & $.357^{\prime \prime}$ & $.371^{4}$ & 1 \\
\hline & Sig. (2-tailed) & .000 & .000 & .000 & .000 & .000 & .000 & .000 & \\
\hline & $\mathrm{N}$ & 1018 & 1018 & 1018 & 1018 & 1018 & 1018 & 1018 & 1018 \\
\hline
\end{tabular}

\section{Practical Application of LIFT in Executive Coaching}

The opportunity to apply some of the key features of LIFT in executive coaching and leadership development include:

1. Adopting a lifespan perspective on leadership with clients.

2. Exploring the leader identity formation process for clients across different periods in their life. 
3. Exploring the formation of a client's leader identity across multiple life domains including their family, friendship and community.

4. Investigating Enabling factors at the Individual level including Change Readiness and Strengths and Authenticity.

5. Investigating Enabling factors at the Relational level including Validating Others and strengthening Social Resources.

6. Investigating Enabling factors at the Collective level including Environmental factors.

7. Developing mitigating strategies to address Derailing factors at the individual (Self-Derailers) and collective level (Environmental Derailers).

Each of the elements of the LIFT model, and corresponding suggested Coaching questions, are outlined in Table 6 . These are suggested to enable executive coaches and development practitioners to actively apply a leader identity approach with their clients, assisting them in supporting and strengthening their clients' leader identity and by extension, their clients' leader effectiveness.

Table 6: LIFT Model Application and Potential Coaching Questions

\begin{tabular}{|c|c|c|}
\hline LIFT Model & Application Description & Coaching Questions \\
\hline $\begin{array}{l}\text { 1. Formation } \\
\text { across the } \\
\text { Lifespan }\end{array}$ & $\begin{array}{l}\text { Coaching questions which adopt a lifespan perspective } \\
\text { enable clients to craft a coherent leader narrative. This } \\
\text { perspective helps clients make sense of their life story and } \\
\text { cast a leadership frame over stages of their life that they } \\
\text { may not have considered relevant. From this narrative } \\
\text { perspective, the client's retelling of their leadership } \\
\text { experiences take the form of a storytelling dynamic, } \\
\text { enabling the client to define and integrate leadership more } \\
\text { strongly within their sense of self. This perspective builds } \\
\text { on a rich stream of narrative research supporting } \\
\text { storytelling as a vehicle for identity formation (Chui Lai } \\
\text { Man, 2018; Lawrence, 2018; Shamir \& Eilam, 2005). } \\
\text { Given the discursive nature of coaching engagements, even } \\
\text { coaches who do not actively address identity change can } \\
\text { provide ways that their clients internalise, form and reform } \\
\text { their identities. }\end{array}$ & $\begin{array}{l}\text { - What does leadership mean to you? } \\
\text { - What were some pivotal moments } \\
\text { in your life when you learnt about } \\
\text { leadership? } \\
\text { - How did you define leadership in } \\
\text { your younger years? } \\
\text { - How has your definition for leading } \\
\text { evolved over time? } \\
\text { - What factors have supported your } \\
\text { leadership over your life? } \\
\text { - What factors have undermined your } \\
\text { leadership over your life? } \\
\text { - How strongly are your leadership } \\
\text { stories connected to hierarchy? } \\
\text { - How would your definition of } \\
\text { leadership change if you separated } \\
\text { leading from hierarchy? }\end{array}$ \\
\hline
\end{tabular}




\begin{tabular}{|c|c|c|}
\hline $\begin{array}{l}\text { 2. Formation } \\
\text { across specific } \\
\text { life periods }\end{array}$ & $\begin{array}{l}\text { Specific coaching questions which inquire into a client's } \\
\text { different life periods may illuminate new perspectives on } \\
\text { the client's leader identity formation process. By } \\
\text { spotlighting the different life periods through targeted } \\
\text { coaching questions, previously hidden enabling and } \\
\text { derailing factors (that influenced the client's leader identity } \\
\text { formation) may be revealed, building their self-awareness } \\
\text { and creating new possibilities for managing these factors } \\
\text { into the future. }\end{array}$ & $\begin{array}{l}\text { - How strongly do you see yourself } \\
\text { as a leader today? } \\
\text { - How strongly did you see yourself } \\
\text { as a leader a year ago? As a young } \\
\text { adult? As a teenager? As a child? } \\
\text { - What did leadership look like at } \\
\text { these periods in your life? } \\
\text { - How does recognising yourself as a } \\
\text { leader in the past help you today? }\end{array}$ \\
\hline $\begin{array}{l}\text { 3. Formation } \\
\text { across multiple } \\
\text { life domains } \\
\text { (identity } \\
\text { workspaces) }\end{array}$ & $\begin{array}{l}\text { The sensemaking process of assisting the client in making } \\
\text { connections across various domains of their life provides } \\
\text { powerful opportunities for them to access all of their } \\
\text { available personal resources and strengths, translating these } \\
\text { to their workplace. This strategy may be particularly useful } \\
\text { for clients who do not yet identify as a leader at work } \\
\text { (Under-Developed stage) but who may be leading in their } \\
\text { family, friendship, or community domains. }\end{array}$ & $\begin{array}{l}\text { - What does your leadership look like } \\
\text { outside of your work? } \\
\text { - How do you lead with your family? } \\
\text { With your friends? } \\
\text { - What kind of leadership do you } \\
\text { show in your community? } \\
\text { - What other areas of your life are } \\
\text { you leading? How different (or } \\
\text { similar) are these leadership } \\
\text { qualities to the ones you use in your } \\
\text { work? }\end{array}$ \\
\hline $\begin{array}{l}\text { 4. Impact of } \\
\text { Enablers - } \\
\text { Individual level }\end{array}$ & $\begin{array}{l}\text { The correlation of leader identity with Change Readiness } \\
\text { and Strengths and Authenticity reinforces their application } \\
\text { in coaching and development. As coaches actively inquire } \\
\text { across the range of possible enablers, such as the client's } \\
\text { strengths deployment (Niemiec, 2019) and their } \\
\text { willingness to embark on a developmental change journey } \\
\text { (Grant, 2014), the results of this current study suggest these } \\
\text { enablers may also contribute towards strengthening the } \\
\text { client's deeper level structure, their leader identity. }\end{array}$ & $\begin{array}{l}\text { - How open and willing are you to } \\
\text { experience change? } \\
\text { - How do you increase your readiness } \\
\text { to change? } \\
\text { - What strengths do you bring to your } \\
\text { leadership? } \\
\text { - How often are you using your } \\
\text { strengths as you lead? What does } \\
\text { this look like? }\end{array}$ \\
\hline $\begin{array}{l}\text { 5. Impact of } \\
\text { Enablers - } \\
\text { Relational level }\end{array}$ & $\begin{array}{l}\text { The positive correlation of leader identity with Validating } \\
\text { Others reinforces the value of amplifying a relational } \\
\text { perspective in executive coaching. The findings in this } \\
\text { study suggest that the claiming and granting of leadership } \\
\text { behaviours that occur in coaching engagements is fertile } \\
\text { soil for accelerating the identity formation process. As an } \\
\text { example, during a coaching session, every interaction } \\
\text { between the coach and client that grants the client's claim } \\
\text { towards leading (by agreeing with their claims to } \\
\text { leadership), can assist the client internalise a leader } \\
\text { identity. Further, actively adopting a relational lens in } \\
\text { coaching allows the client's socially derived identity }\end{array}$ & $\begin{array}{l}\text { - How do you validate the leadership } \\
\text { in others? } \\
\text { - What does validating others' } \\
\text { leadership mean to you? } \\
\text { - How do you create the space for } \\
\text { others to lead? } \\
\text { - How often do you recognise the } \\
\text { leadership in those around you? } \\
\text { What does this look like? } \\
\text { - How actively are you taking action } \\
\text { as a leader? }\end{array}$ \\
\hline
\end{tabular}




\begin{tabular}{|c|c|c|}
\hline & $\begin{array}{l}\text { aspects to emerge and be positively explored, enhancing } \\
\text { awareness of the importance of quality, relational } \\
\text { connections (Dutton, Roberts, \& Bednar, 2010). }\end{array}$ & $\begin{array}{l}\text { - How is your initiative taking as a } \\
\text { leader received by those around } \\
\text { you? }\end{array}$ \\
\hline $\begin{array}{l}\text { 6. Impact of } \\
\text { Enablers - } \\
\text { Collective level }\end{array}$ & $\begin{array}{l}\text { Environmental derailers represent a collective level factor } \\
\text { which may require a more complex level of awareness and } \\
\text { cognitive complexity (Lord et al., 2020).. This factor } \\
\text { presents another powerful area of inquiry for executive } \\
\text { coaches, as they investigate the influence of collective } \\
\text { norms for leadership, organisational processes, culture and } \\
\text { social forces that their client may (or may not) recognise. } \\
\text { This collective-level identity processing may also be } \\
\text { evoked through assisting the client to identify and } \\
\text { strengthen their collective ties (their Social Resources) and } \\
\text { their awareness of the underlying socio-economic } \\
\text { dynamics that may be impeding their identity formation } \\
\text { (Chui Lai Man, 2018). Furthermore, executive coaches can } \\
\text { actively contribute to positive organisational cultures by } \\
\text { helping clients strengthen their collective level identity as a } \\
\text { leader, proactively building positive interdependencies with } \\
\text { others (Cameron \& McNaughtan, 2014). }\end{array}$ & $\begin{array}{l}\text { - What are your company's norms for } \\
\text { leading? What style of leadership is } \\
\text { accepted and not accepted? } \\
\text { - Who is expected to lead, and not to } \\
\text { lead, in your organisation? } \\
\text { - How does your leadership approach } \\
\text { align (or not align) with the } \\
\text { leadership culture of your } \\
\text { organisation? } \\
\text { - What relationships in your } \\
\text { workplace support your leadership? } \\
\text { - How do you cultivate leadership } \\
\text { perceptions with those around you? }\end{array}$ \\
\hline $\begin{array}{l}\text { 7. Impact of } \\
\text { Derailers and } \\
\text { mitigating } \\
\text { strategies }\end{array}$ & $\begin{array}{l}\text { Through active listening and mindful attention, by the } \\
\text { coach and client, potential derailers in identity formation } \\
\text { may be mitigated. By recognising the socially situated } \\
\text { context of every client, the complexity of their situations } \\
\text { can emerge, and the interdependencies of their identity } \\
\text { become more known. Exploring identified enablers and } \\
\text { derailers, in a psychologically safe space, helps surface } \\
\text { strategies that can equipp clients to actively address them. }\end{array}$ & $\begin{array}{l}\text { - What are the factors in your current } \\
\text { experience that support or } \\
\text { undermine your sense of self as a } \\
\text { leader? } \\
\text { - What influences are you facing that } \\
\text { seem to destabilise your sense of } \\
\text { self as a leader? } \\
\text { - What influences strengthen your } \\
\text { leader identity? }\end{array}$ \\
\hline
\end{tabular}

\section{Study imitations and Future Research}

A number of limitations are noted with the current study. First, the selfreported, retrospective nature of the data is prone to bias (Gardner et al., 2020). However, given the subjectivity associated with leader identity and the factors one might perceive to impact it, the collection of self-report data seemed appropriate (Miscenko et al., 2017). Second, the survey items used are in need of further validation and cannot yet be claimed to be psychometrically robust. As such, any interpretations made from these results need to be tentatively advanced. Nonetheless, the variables considered in this study would seem to warrant further investigation and, ideally, with more sophisticated statistical 
methods (e.g., structural equation modelling) that can help to more precisely identify the role of enablers and derailers in the leader identity formation process. As noted by Chui (2018), "the investigation of leader identification as a process or as a construct is still only emerging and deserves a more systematic approach in examining the related antecedents and outcomes" (p. 200). Likewise, future research into leader identity formation processes occurring within and across life domains such as family and community, is required. Future testing could also include whether the arbitrary definition of the five life periods in the survey questions limited the identification (or measurement) of any potential within-period formation that participants experienced.

\section{Conclusion}

Sustainable leadership growth does not come through a singular focus on leadership behaviours and skills (Day \& Dragoni, 2015; Lord et al., 2020; Skinner, 2020). Sustainable leadership change is enabled through deeper level changes which incorporate the individual's sense of self, their leader identity, as well as their skill development (Hammond et al., 2017; Miscenko et al., 2017). This study contributes towards addressing a gap in the leader identity literature consisting of a lack of empirical investigations measuring the lifespan approach to leader identity formation, and the impact of factors which may enable or derail this process. Whilst the findings in this study require further research, they provide initial empirical support for Leader Identity Formation Theory (LIFT) (Skinner, 2020). LIFT illuminates several avenues for enabling deeper level leadership processing, including understanding the ways in which leader identity varies over one's lifetime and the relationship of identity strength with enabling and derailing factors. As stated earlier, further investigation of these findings is warranted, investigating the interplay between individual, relational and collective factors, and self-construal in identity formation (Chui 2018).

Executive coaches can play a fundamental role in facilitating the intrapersonal and interpersonal leader identity formation process. The lifespan results of this study support the centrality of leader identity for individuals within organisations and provides fertile ground for leader identity coaching exploration. Through applying a lifespan lens to leadership, coaches are in a prime position to accelerate their clients' leadership growth. The small to moderate correlations of each of the enabling factors supports the sensemaking that can be provided in executive coaching sessions, exploring their possible impact on the client's internalisation process. By greater narrative role-claiming as a leader and articulating one's unique leader identity, coaches can facilitate their client's internal knowledge structure for leading, enhancing both their 
leadership skill development and their leader effectiveness (Clapp-Smith et al., 2019; Kragt \& Day, 2020). In line with observations throughout the leader identity literature (Epitropaki et al., 2017; Kragt \& Day, 2020; Miscenko et al., 2017), leadership development, and by extension, executive coaching, can be greatly enhanced by a closer integration of leader identity coaching perspectives within these interventions.

\section{References:}

Acton, B. P., Foti, R. J., Lord, R. G., \& Gladfelter, J. A. (2019). Putting emergence back in leadership emergence: A dynamic, multilevel, process-oriented framework. The Leadership Quarterly, 30(1), 145-164.

Ashforth, B. E., \& Schinoff, B. S. (2016). Identity under construction: How individuals come to define themselves in organizations. Annual Review of Organizational Psychology and Organizational Behavior, 3, 111137.

Bachkirova, T. (2016a). Developmental coaching: theory and practice In Coaching. Als individuelle Antwort auf gesellschaftliche Entwicklungen (pp. 295-306): Springer VS, Wiesbaden.

Bachkirova, T. (2016b). The Self of the Coach: Conceptualization, Issues, and Opportunities for Practitioner Development (Vol. 68). Educational Publishing Foundation.

Cameron, K., \& McNaughtan, J. (2014). Positive organizational change. The Journal of Applied Behavioral Science, 50(4), 445-462.

Chui Lai Man, S. (2018). Construction and impact of leader identity of dynamic work selves at social enterprises: Linkage of the intrapersonal and interpersonal processes with motivational work outcomes. ( $\mathrm{PhD})$. Durham University,

Clapp-Smith, R., Hammond, M. M., Lester, G. V., \& Palanski, M. (2019). Promoting identity development in leadership education: A multidomain approach to developing the whole leader. Journal of Management Education, 43(1), 10-34.

Clark, P. M. (2018). Protecting and serving her way: A qualitative inquiry of female law enforcement leaders' social identity and leader self-efficacy. (PhD). The George Washington University,

Day, D. V, \& Dragoni, L. (2015). Leadership development: An outcomeoriented review based on time and levels of analyses. Annual Review of Organizational Psychology and Organizational Behavior, 2(1), 133156. 
Day, D. V., Fleenor, J. W., Atwater, L. E., Sturm, R. E., \& McKee, R. A. (2014). Advances in leader and leadership development: A review of 25 years of research and theory. The Leadership Quarterly, 25(1), 63-82.

Day, D. V., \& Harrison, M. M. (2007). A multilevel, identity-based approach to leadership development. Human Resource Management Review, 17(4), 360-373.

Day, D. V., \& Sin, H.-P. (2009). Leader Development, Identity and Goal Orientation: A study of personal change trajectories. In Leader Development, Identity, and Goal Orientation: A Study of Personal Change Trajectories (pp. 1-6). Academy of Management. .

DeRue, D. S., \& Ashford, S. J. (2010). Who will lead and who will follow? A social process of leadership identity construction in organizations. Academy of Management Review, 35(4), 627-647.

DeRue, D. S., \& Myers, C. G. (2014). Leadership development: A review and agenda for future research. In D. Day (Ed.), Oxford Handbook of Leadership and Organizations. London: Oxford University Press.

Dutton, J. E., Roberts, L. M., \& Bednar, J. (2010). Pathways for positive identity construction at work: Four types of positive identity and the building of social resources. Academy of Management Review, 35(2), 265-293.

Epitropaki, O., Kark, R., Mainemelis, C., \& Lord, R. G. (2017). Leadership and followership identity processes: A multilevel review. The Leadership Quarterly, 28(1), 104-129.

Gardner, W. L., Lowe, K. B., Meuser, J. D., Noghani, F., Gullifor, D. P., \& Cogliser, C. C. (2020). The leadership trilogy: A review of the third decade of the leadership quarterly. The Leadership Quarterly, 31(1), 126.

Grant, A. M. (2014). The efficacy of executive coaching in times of organisational change. Journal of Change Management, 14(2), 258-280.

Guillén, L., Mayo, M., \& Korotov, K. (2015). Is leadership a part of me? A leader identity approach to understanding the motivation to lead. The Leadership Quarterly, 26, 802-820.

Hammond, M., Clapp-Smith, R., \& Palanski, M. (2017). Beyond (just) the workplace: A theory of leader development across multiple domains. Academy of Management Review, 42(3), 481-498.

Ibarra, H. (1999). Provisional selves: Experimenting with image and identity in professional adaptation. Administrative Science Quarterly, 44(4), 764791.

Ibarra, H., Wittman, S., Petriglieri, G., \& Day, D. V. (2014). Leadership and identity: An examination of three theories and new research directions. 
In The Oxford Handbook of Leadership and Organizations (pp. 285300). Oxford Online: Oxford University Press.

Johnson, R. E., Venus, M., Lanaj, K., Mao, C., \& Chang, C.-H. (2012). Leader identity as an antecedent of the frequency and consistency of transformational, consideration, and abusive leadership behaviors. Journal of Applied Psychology, 97(6), 1262-1272.

Karelaia, N., \& Guillén, L. (2014). Me, a woman and a leader: Positive social identity and identity conflict. Organizational Behavior and Human Decision Processes, 125(2), 204-219.

Kragt, D., \& Day, D. V. (2020). Predicting leadership competency development and promotion among high-potential executives: The role of leader identity. Frontiers in Psychology, 11(1816), 1-16.

Kragt, D., \& Guenter, H. (2018). Why and when leadership training predicts effectiveness: The role of leader identity and leadership experience. Leadership \& Organization Development Journal, 39(3), 406-418.

Ladge, J. J., Clair, J. A., \& Greenberg, D. (2012). Cross-domain identity transition during liminal periods: Constructing multiple selves as professional and mother during pregnancy. Academy of Management Journal, 55(6), 1449-1471.

Lanka, E., Topakas, A., \& Patterson, M. (2019). Becoming a leader: catalysts and barriers to leader identity construction. European Journal of Work and Organizational Psychology, 1-14.

Lawrence, P. (2018). A narrative approach to coaching multiple selves. International Journal of Evidence Based Coaching \& Mentoring, 16(2), 32-41.

Liu, Z., Riggio, R. E., Day, D. V., Zheng, C., Dai, S., \& Bian, Y. (2019). Leader development begins at home: Overparenting harms adolescent leader emergence. Journal of Applied Psychology, 104(10), 1226-1242.

Lord, R. G., Epitropaki, O., Foti, R. J., \& Hansbrough, T. K. (2020). Implicit leadership theories, implicit followership theories, and dynamic processing of leadership information. Annual Review of Organizational Psychology and Organizational Behavior, 7, 49-74.

Lord, R. G., \& Hall, R. J. (2005). Identity, deep structure and the development of leadership skill. The Leadership Quarterly, 16(4), 591-615.

Marchiondo, L. A., Myers, C. G., \& Kopelman, S. (2015). The relational nature of leadership identity construction: How and when it influences perceived leadership and decision-making. The Leadership Quarterly, 26(5), 892-908.

Markus, H., \& Kunda, Z. (1986). Stability and malleability of the self-concept. Journal of Personality and Social Psychology, 51(4), 858-866. 
Markus, H., \& Wurf, E. (1987). The dynamic self-concept: A social psychological perspective. Annual Review of Psychology, 38(1), 299337.

Miscenko, D. (2017). Leader development: An identity-based perspective. $(\mathrm{PhD})$. The University of Western Australia.

Miscenko, D., Guenter, H., \& Day, D. V. (2017). Am I a leader? Examining leader identity development over time. The Leadership Quarterly, 28(5), 605-620.

Murphy, S. E., \& Johnson, S. K. (2011). The benefits of a long-lens approach to leader development: Understanding the seeds of leadership. The Leadership Quarterly, 22(3), 459-470.

Niemiec, R. M. (2019). Finding the golden mean: the overuse, underuse, and optimal use of character strengths. Counselling Psychology Quarterly, 32(3-4), 453-471.

Nyberg, D., \& Sveningsson, S. (2014). Paradoxes of authentic leadership: Leader identity struggles. Leadership, 10(4), 437-455.

Petriglieri. (2011). Under threat: Responses to and the consequences of threats to individuals' identities. Academy of Management Review, 36(4), 641662.

Petriglieri, G., \& Stein, M. (2012). The unwanted self: projective identification in leaders' identity work. Organization Studies, 33(9), 1217-1235.

Romaniuk, M.-J. H. (2014). Developing emerging leaders in the library profession: Program content, self-efficacy and leadership. (PhD). Queensland University of Technology,

Shamir, B., \& Eilam, G. (2005). "What's your story?" A life-stories approach to authentic leadership development. The Leadership Quarterly, 16(3), 395-417.

Skinner, S. (2014). Understanding the importance of gender and leader identity formation in executive coaching for senior women. Coaching: An International Journal of Theory, Research and Practice, 7(2), 102-114.

Skinner, S. (2015). Build Your Leader Identity: A Practical Guide to Leading Authentically from Any Position. Sydney, Australia: Longueville Publishing.

Skinner, S. (2020). Towards a theory of leader identity formation and its application in executive coaching. Philosophy of Coaching: An International Journal, 5(1), 71-89.

Taber, K. S. (2018). The Use of Cronbach's Alpha When Developing and Reporting Research Instruments in Science Education. Research in Science Education, 48(6), 1273-1296. 
Weiss, I., \& Fisherman, S. (2011). Cognitive and personality factors in teachers' training: Comparison of college to university students. Curriculum and Teaching, 26(1), 33-55.

Zheng, W., \& Muir, D. (2015). Embracing leadership: a multi-faceted model of leader identity development. Leadership \& Organization Development Journal, 36(6), 630-656.

\author{
Author Contact \\ Dr Suzi Skinner \\ Director, Roar People \\ Sydney, NSW \\ Australia \\ E: suzi@roarpeople.com.au
}

